\title{
An Educational Experience with a Focus on Plants: Capacity Building in Nutrition Students in a Brazilian Laboratory- Vegetable Garden
}

\author{
Joana Yasmin Melo De Araujo, Laura Brito Porciuncula, \\ and Thiago Perez Jorge
}

\section{Contents}

1 Introduction. .......................................................... 395

2 Materials and Methods......................................................... 397

3 The GBL Proposal as Developed in LabNutrir. ................................. 398

4 Unconventional Food Plants: An Axis in Education to Promote Biodiversity and Sustainable Diets................................................ 400

5 An Answer for the Future: GBL for Professional Training of Nutritionists............ 406

6 Final Considerations...................................................... 410

References.............................................................. 411

\section{Introduction}

The global agenda for sustainable development (emphasizing the United Nations Agenda for 2030, UN 2017) points to the need for investment in training of professionals ready in their practice to recognize and address the impacts of food systems $^{1}$ (Jacob and Araújo 2019). Among such professionals, the nutritionist stands out, since his practice (the task of thinking about diet) integrates relevant aspects of human and environmental health (Lang and Barling 2013). In view of

\footnotetext{
${ }^{1}$ Food systems deal with all actors and their interrelated activities in "production, aggregation, processing, distribution, consumption, and disposal of food." They consist of several subsystems, such as agriculture and food supply, and, with the multiplicity of participants and dimensions involved in the systems, have impacts on the social, economic, and environmental scales on a global scale (FAO 2013).
}

J. Y. M. De Araujo

Departamento de Nutrição, Universidade Federal do Rio Grande do Norte, Natal, Brazil

L. B. Porciuncula T. P. Jorge $(\bowtie)$

Nutrition Department, Federal University of Rio Grande do Norte, Natal, Brazil

e-mail: lauraporciunc@ufrn.edu.br 
this, by working toward sustainable diets, the nutritionist might lead in the construction of sustainable food systems. According to the Food and Agriculture Organization of the United Nations (FAO), sustainable diets present low environmental impact: they contribute to a healthy life for present and future generations, are protective and respectful of biodiversity and ecosystems, are culturally acceptable and accessible, are economically fair and accessible, are nutritionally adequate and safe, and optimize natural resources (Burlingame and Dernini 2012).

In addition to that, if on one hand, excessive fragmentation of knowledge in nutritionist training, in most cases, favors an approach focused only on nutrients (Azevedo and Rigon 2016), neglecting social, environmental, and economic contexts, on the other hand, it has also presented a slow evolution toward incorporation (into curricular structures) of new concepts and questions concerning sustainable development. The official Brazilian document in force for higher education in Nutrition dates back to 2001 and when dealing with the contents to be covered during training explains environmental themes only once, as part of understanding "ecological" determinants (Brasil 2001).

However, the 2013 "Consensus document concerning skills and competency of nutritionists in the field of public health," being relevant to the entire field, incorporates the dimensions of sustainability and biodiversity, as being based on four professional competencies that must be contained in training courses, being intrinsic to delineation of the new professional:

1. Identify and value aspects related to sustainability and food consumption and incorporate them into Food and Nutrition Education practices;

2. Promotion of a sustainable food supply;

3. Identify and analyze the relationship between behavior, eating habits, culture, territoriality, sustainability, and food diversity.

4. Promotion of water quality in the context of the Human Right to Adequate Food. (Recine and Mortoza 2013)

It is with this formative concern that the Community Garden/Horta (LabNutrir) emerges, seeking to incorporate and strengthen the topic of sustainability in nutrition training. The vegetable garden laboratory brings an agroecological perspective to growing food, of teaching, and of research and extension aimed at learning about food and nutrition with a focus on the biodiversity of unconventional food plants (UFP). The applied methodology is garden-based learning (GBL), which uses vegetable gardens as teaching tools (Desmond et al. 2004).

In this chapter, we will present the experience at LabNutrir to exemplify how UFP can be approached based on GBL as we share instruments and ideas we developed with our students. Also, we will explore the perception of Nutrition students with respect to the potential knowledge, skills, and attitudes that they observe and experienced in GBL strategy considering their living in LabNutrir. 


\section{Materials and Methods}

This study is qualitative and describes the GBL method, analyzing the effects of teaching nutrition with plants; and we will use the case study approach (Creswell 2014).

In this case, we intended to evaluate the learning process at LabNutrir with the starting question: how can teaching and learning of sustainability and biodiversity be developed though the GBL method? This starting point is the motivation for us to present the outcomes of using UFP as a learning and teaching tool with undergraduate students of Nutrition and their perspectives concerning knowledge, abilities, and attitudes developed in LabNutrir. It should be noted that the authors are members of the study site/locale, which is why the text takes the form of an experience report. The data were obtained through two combinations:

1. Collection and examination of data sheets produced during 2019, on the eight non-conventional food plants studied, being available on the Project website. ${ }^{2}$ These data sheets systematize information concerning the UFP - scientific name of the plant, photography, vernacular names, origin, occurrence biome, food uses, indicators of nutritional composition (macronutrients, micronutrients, and bioactive compounds), and references. In this way, we choose this tool to systematize UFP information based on the idea that it materializes the transdisciplinary approach applied through GBL method, as the students involved in this data collection have to connect production and consumption of the species thought ethnobotanical interviews and research, and thus it supports for the education development in food and nutrition, focused especially on biodiversity during the conception of it, and the product is a tool of easy, accessible, and democratic scientific dissemination.

2. Semi-structured interviews carried out with four students by telephone. In 2019, of the ten students directly involved in the project, four had joined this year. Thus, it was decided to choose these students to assess the potential of GBL method in a short period of time in comparison to other students of the project. The interviews were conducted in late 2019 by telephone. The conversations were recorded, and their content was transcribed. A floating reading allowed first contact and organization of the material. Students' speeches will be used in both sessions, firstly, as basis to emphasize benefits from the GBL method. For categorical aggregation in the three items of capacity building (knowledge, skills and attitudes), we opted for direct interpretation of students' responses (Creswell 2014).

Conceptually, competencies are structured cognition modalities, that is, they refer to the relationships between people, objects, situations, and phenomena that one desires to understand. Skills, on the other hand, stem from the competencies acquired by the individual and refer to immediate "know-how." Thus, through

\footnotetext{
${ }^{2}$ See at www.nutrir.com.vc/blog/biodiversidade/
} 
actions and operations, skills improve and articulate themselves, aiming at a new (re)organization of competences (Brasil 2000). Strictly speaking, capacity building is not carried out in isolation. For the future professional, thinking, doing, living, and being are intrinsically linked to competencies and skills development. Thus, in each answer from the academics, all from the nutrition course, we obtain an example necessary for construction of categories of analysis with respect to the development of knowledge, skills, and attitudes.

Thus, it is of extreme importance to say that it is not possible to "teach" competencies. According to Perrenoud (2008), from the perspective of the subject of education, instead of a "teaching" process, there is a mobilization of his mind from resources, skills, and knowledge with the starting point of any demand (i.e., needs and new or unforeseen situations). Thereby, capacity building emphasizes the pedagogical method and the learning situation, overcoming the false theory-practice dichotomy.

\section{The GBL Proposal as Developed in LabNutrir}

The Community Garden-Based Laboratory (GBL) (LabNutrir) is located on the central campus of the Federal University of Rio Grande do Norte, in the city of Natal, Northeastern Brazil. Natal is the capital of Rio Grande do Norte and has the largest population in the state, with more than 800,000 inhabitants.

LabNutrir covers an area of $1200 \mathrm{~m}^{2}$ divided into different growing beds, scattered plantings, an orchard, a pollinator garden, compost space, seedling nursery, bee houses, two circular areas for group conversations, and a space for tool storage. In accordance with agro-ecological practices, no chemical-based fertilizers or pesticides are used. We have more than 131 edible plant species in LabNutrir, ${ }^{3}$ distributed over 55 different botanical families; half of them are UFP.

Opened in November 2017 as the Community Nutrition Garden (HCN, in Portuguese), as a result of the need to incorporate local biodiversity into the curriculum, it was institutionalized in April 2019 as a laboratory of the Department of Nutrition of the Federal University of Rio Grande do Norte (UFRN) (Fig. 1).

Institutionalization of the first open-air laboratory in Brazil guaranteed the maintenance of the space, greater fundraising, and autonomy, with recognition of the legitimacy of the garden as a structure of excellence in teaching and learning, within a perspective that links biodiversity to nutritionist training in both content and skills.

Thus, an approach was sought that dealt with differing fields of knowledge in a transversal way, an active and transdisciplinary methodology where students are invited to deal critically and reflectively with the problems and solutions involved in the themes worked experientially, from the physical space, and in management of a vegetable garden (Desmond et al. 2004; Jacob 2020).

${ }^{3}$ Check our inventarium at http://nutrir.com.vc/horta/Completo.pdf 


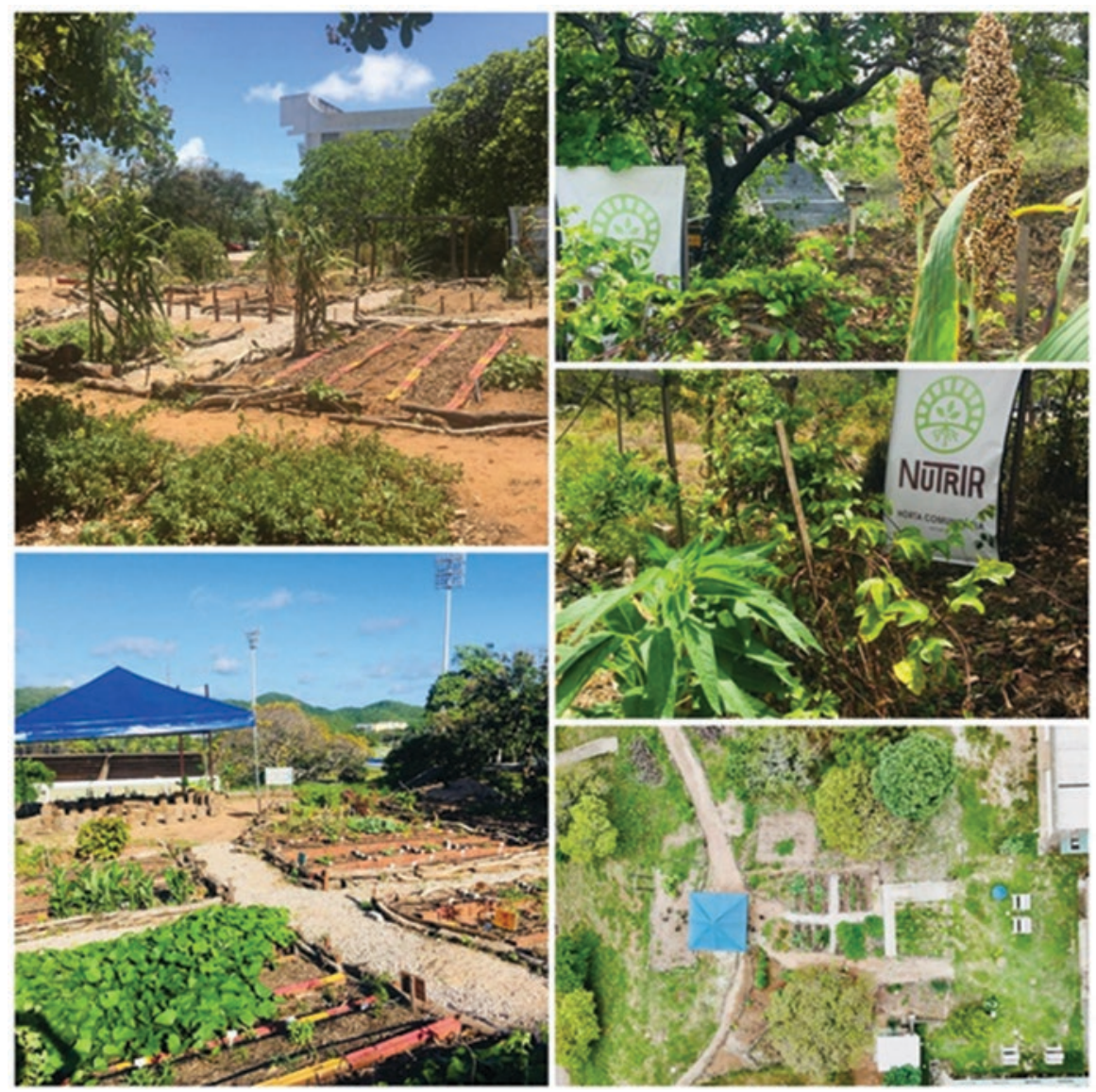

Fig. 1 The LabNutrir physical space. (Source: LabNutrir)

Thus, to put the GBL method into practice, the creators of the then HCN sought a theme (to guide their pedagogy) that reconciled the integration of curricular components of different teaching departments at UFRN: Agronomy, Botany, Ecology, and Nutrition. In this way, we came to the topic of UFP, the main axis of the GBL method. UFP are characterized as edible plants, exotic or native, which are often hard to identify or inaccessible to a certain population to buy. Their definition varies in time and space, depending on whether these plants are part of the usual diet of a given community, and thus, it offers the potential to contribute with food and nutrition security, health, generation of income, and ecological integrity (Jacob 2020).

At LabNutrir, planning each semester, the UFP that will be studied in the following term are selected in a wide debate involving the Garden/Horta members. In 2019, the laboratory-garden had 5 teachers, 3 assistants, 10 student monitors, and 20-30 volunteers, including students from various courses at UFRN and residents of the metropolitan region of Natal-RN. 
The following sections present our results and discussions. We start presenting the result of a data collection instrument developed at LabNutrir to study the UFP during the year of 2019 among our students, as a training strategy for the promotion of environmental sustainability based on the valorization of local biodiversity. In the next section, we explore the perceptions of impacts on the teaching and learning process based on the potential of acquisition of knowledge, skills, and attitudes involved in the GBL method with their experience in the garden lab.

\section{Unconventional Food Plants: An Axis in Education to Promote Biodiversity and Sustainable Diets}

It is known that Brazil as a country presents the greatest biological diversity in the world; its flora represents more than $20 \%$ of the total species existent on the planet (Martinelli and Moraes 2013). However, loss of food biodiversity is a global reality and affects large reservoirs of biological diversity on the planet, noting that more than half of the energy currently consumed globally comes from only four crops: rice, potatoes, wheat, and corn (FAO 2010).

In this panorama, there is a huge amount of edible plants' species underexploited, and thus they are classified as unconventional. Even so, their use in traditional communities is rescued, thinking cultural heritage and local ethnoculinary are distant from and less influenced by the urban globalization process. Also, these plants are of great ecological and economic importance to local communities (Kinupp and De Barros 2008; Kinupp and Lorenzi 2014; UN 2017). To this matter, UFP are a medium for several lines of study, including Ethnobotany, Agroecology, Biodiversity, Sustainability, and Nutrition.

UFP can well function as a tool for multidisciplinary studies with biocultural perspectives. They fit in as plants which strengthen food biodiversity, being essential for construction of sustainable diets. The sustainable diet has been characterized according to Willett et al. (2019) and Forouhi and Unwin (2019), as one based on plant diversity and, occasionally, moderate amounts of animal protein. To fill gaps involving (1) accessibility of data on food biodiversity, (2) lack of data on culinary use in ethnobotanical studies, and (3) lack of data on nutritional composition, Jacob and Albuquerque (2020) reveal the need for this perspective.

Elaboration of sustainable menus or diets by nutritional professionals has been limited, this considering that the principal tools involving nutritional assessment do not consider culture and, for the most part, do not contain data that relate biodiversity between species and subspecies (Fao 2017; Jacob and Albuquerque 2020).

LabNutrir seeks to overcome these limitations with the implementation of activities for the development of UFP. The data sheets serve as instruments of scientific dissemination that allow simultaneous analysis of the plants, the people, and their diets, in addition to corroborating the dialogue between nature and food plant culture. The instrument assists in design activities involving Food and Nutrition 
Education within the community, whether in practical classes, culinary workshops, or agricultural management (Etkin 2006; Tumilowicz et al. 2016; Jacob 2020).

For this, the data sheets were developed: for compiling data related to food biodiversity, assisting in the propagation of their content, and bringing knowledge of the nutritional and cultural nature of the plants. They serve as training instruments for nutrition professionals and contribute to an education that overcomes the barriers of nutritionism. ${ }^{4}$

Each semester, four UFP are chosen for research among students, project team, and community. Favorable conditions for plant development, functionality for recipes, and seasonality are considered when choosing which UFP to work with. The variables selected for collection are representative photos of the species, popular names and uses, morphological characteristics, origin, ecology of the species, propagation and cultivation, food uses, nutritional information, toxicity, and a recipe, once they are the main gaps for access and recognition of these species by the population. This activity is associated as main research of the four curricular components associated with LabNutrir: Socio-anthropological Aspects of Human Food, Food and Nutrition Education, Principles of Agroecology, and Sustainable Food Systems. In this way, students of this component carry out research in scientific databases, by culinary practice and through ethnobotanical surveys carried out with the local population.

After their collection and interviews, the information is compiled and edited by student monitors linked to the project, who structures the final product of the data sheets. The teachers perform a review of the material, possibly indicating more in-depth searches and aligning the information. Finally, the sheets are made available in the Project website, ${ }^{5}$ as a tool for scientific dissemination of easy access. This workflow of how the data sheets are made is being represented in Fig. 2.

By 2019, 131 species of plants were identified in the garden space, where 64 were characterized as unconventional and/or medicinal and 35 as native, such as Jurubeba (Solanum paniculatum L.), Cariru (Talinum triangulare (Jacq.) Willd.), Taioba (Xanthosoma taioba E.G. Gonç), and Couvinha (Porophyllum ruderale (Jacq.) Cass), among others. In 2019, eight species plants were cataloged. Table 1 presents the data for scientific name, origin, distribution/occurrence, and food uses of the eight plants cataloged by LabNutrir in 2019, represented in Fig. 3.

With the aim of demonstrating education outcomes specially related to sustainable food systems, food biodiversity, and food and nutrition education achieved through the elaboration of UFP data sheets, we have made explicit here some speeches from students included in the project that denote in a clear way how this process is operationalized in practice.

To begin, the following sentence of Student 2 "I've learned about UFP and non UFP, discovered that there are specific ways to photograph plants, about plants'

\footnotetext{
${ }^{4}$ Refers to ideological discourses employed by food industry, based on nutrition dietary rationality that reduces the dimensions of food, disconnecting the act of eating of food, diet, environment, and the world (Scrinis 2008).
}

${ }^{5}$ UFP data sheets are available at http://nutrir.com.vc/blog/biodiversidade/ 


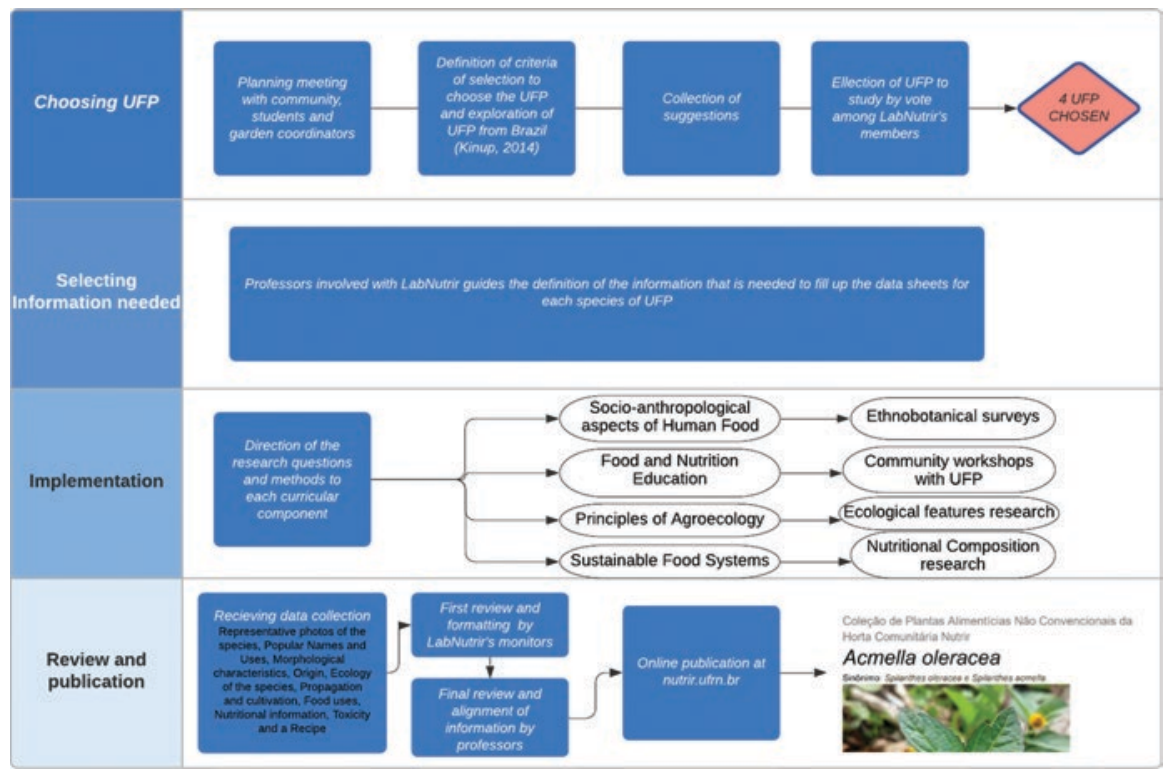

Fig. 2 Workflow for UFP data sheets. (Source: Authors)

families (...)" illustrates the importance of this notion. In this way, it is possible to infer that the recognition of plants' family and common characteristics between species, such as the photography that allows distinguishing details, facilitates, for instance, the comprehension of similar preparation techniques among those species of the same family.

Moreover, when it comes to plants, it is commonplace that there are confusions in the moment of recognition of species, particularly with popular names. With that in mind, acquiring the knowledge about origin, place of occurrence, and scientific name of species helps the understanding about food utilization and proper handling. To this matter, Student 1 says that "I did not have notion about the amount of food available in an easy, economic and biodiverse way," which can be related with Food Uses column of Table 1. This statement exposes a gap around preparation techniques and uses of UFP, once the student reveals that his experience in LabNutrir promoted an amplification of his food perspective and thus made it possible to see new possibilities of preparation and consumption of plants that can enrich local market and contributes with healthier and sustainable food habits, since they encompass biodiversity through UFP.

Furthermore, experiential education obtained through the process of making UFP data sheets, illustrated by Fig. 1 (flowchart), allows us to recognize LabNutrir's importance of broadening the comprehension of Nutrition as socialenvironmental science, once the inclusion of outcomes from the promotion of ethnobotanical surveys with locals brings up the biocultural commonly neglected in this field of knowledge. In this case, food biodiversity comprehension requires 
Table 1 Data from the UFP studied at the Garden/Horta Comunitária Nutrir (HCN) Laboratory in 2019. Natal-RN, Brazil

\begin{tabular}{|c|c|c|c|}
\hline Scientific name & Origin & Distribution/occurrence & Food uses \\
\hline $\begin{array}{l}\text { Moringa } \\
\text { oleifera } \\
\text { Lamarck } \\
\end{array}$ & India & $\begin{array}{l}\text { Africa, Central America, South } \\
\text { America, Sri Lanka, India, Mexico, } \\
\text { Malaysia, and the Philippines }\end{array}$ & $\begin{array}{l}\text { Flowers and leaves, } \\
\text { raw or cooked. } \\
\text { Fruits, cooked }\end{array}$ \\
\hline $\begin{array}{l}\text { Eugenia } \\
\text { pyriformis } \\
\text { Cambess }\end{array}$ & Brazil & Cerrado and Atlantic Forest & $\begin{array}{l}\text { Fruits and leaves, } \\
\text { raw or cooked }\end{array}$ \\
\hline $\begin{array}{l}\text { Cyperus } \\
\text { rotundus } \mathrm{L} \text {. }\end{array}$ & Brazil & $\begin{array}{l}\text { Wide distribution in temperate } \\
\text { tropical and subtropical climate. } \\
\text { Cerrado, Amazon, Atlantic Forest, } \\
\text { and Caatinga }\end{array}$ & $\begin{array}{l}\text { Rhizome, raw, } \\
\text { cooked, or roasted }\end{array}$ \\
\hline $\begin{array}{l}\text { Momordica } \\
\text { charantia } \\
\text { L. "Goya" }\end{array}$ & $\begin{array}{l}\text { East India and } \\
\text { South China }\end{array}$ & All regions of Brazil & $\begin{array}{l}\text { Fruits, blanched, } \\
\text { brine, preserved, } \\
\text { fried, or cooked. } \\
\text { Raw flowers and } \\
\text { leaves }\end{array}$ \\
\hline $\begin{array}{l}\text { Acmella } \\
\text { oleracea }(\mathrm{L} .) \\
\text { R. K. Jansen }\end{array}$ & $\begin{array}{l}\text { India or South } \\
\text { America }^{\text {a }}\end{array}$ & $\begin{array}{l}\text { Tropical regions close to the } \\
\text { Equator in Africa, Asia, and South } \\
\text { America Atlantic Forest and } \\
\text { Amazon }\end{array}$ & $\begin{array}{l}\text { Branches, leaves, } \\
\text { and flowers, raw, } \\
\text { cooked, sautéed, or } \\
\text { roasted }\end{array}$ \\
\hline $\begin{array}{l}\text { Clitoria } \\
\text { ternatea } \mathrm{L} .\end{array}$ & $\begin{array}{l}\text { Indonesia, with } \\
\text { reports in Asia, } \\
\text { South America, } \\
\text { and the Caribbean }\end{array}$ & $\begin{array}{l}\text { All tropical areas of the globe. } \\
\text { America, Asia, and Australia }\end{array}$ & $\begin{array}{l}\text { Flowers, raw. Pods } \\
\text { and leaves, cooked }\end{array}$ \\
\hline $\begin{array}{l}\text { Coccinia } \\
\text { grandis (L.) } \\
\text { Voigt }\end{array}$ & East Africa & $\begin{array}{l}\text { Tropical areas India, Philippines, } \\
\text { Cambodia, China, Indonesia, } \\
\text { Malaysia, Myanmar, Thailand, } \\
\text { Vietnam, eastern Papua New } \\
\text { Guinea, Australia, and the } \\
\text { Americas }\end{array}$ & $\begin{array}{l}\text { Cooked fruits, } \\
\text { leaves and stem }\end{array}$ \\
\hline Oxalis regnellii & South America & Tropical zones of South America & $\begin{array}{l}\text { Leaves, stem, } \\
\text { flowers and bulbs, } \\
\text { raw or cooked and } \\
\text { bleached }\end{array}$ \\
\hline
\end{tabular}

Source: Authors

aPossibly originating from these locations, as there is no consensus in the literature on this information. The most recurring locations are listed as being origins

the understanding that plant species are incorporated via appropriation of uses and customs attributed to historical moments that transmits the culture of traditional communities and people. This idea is reflected by Student 3:

Inside the Garden you are able to see food as a whole, from his genesis to end (...), the principal is related to Food Biodiversity, which is very well placed in practice (...), both inside the gardens' discourse and in task force with community, such as in curricular components associated with it (...), it is also exercised the thing about contact with the earth. I used to see Nutrition in a more closed way. 

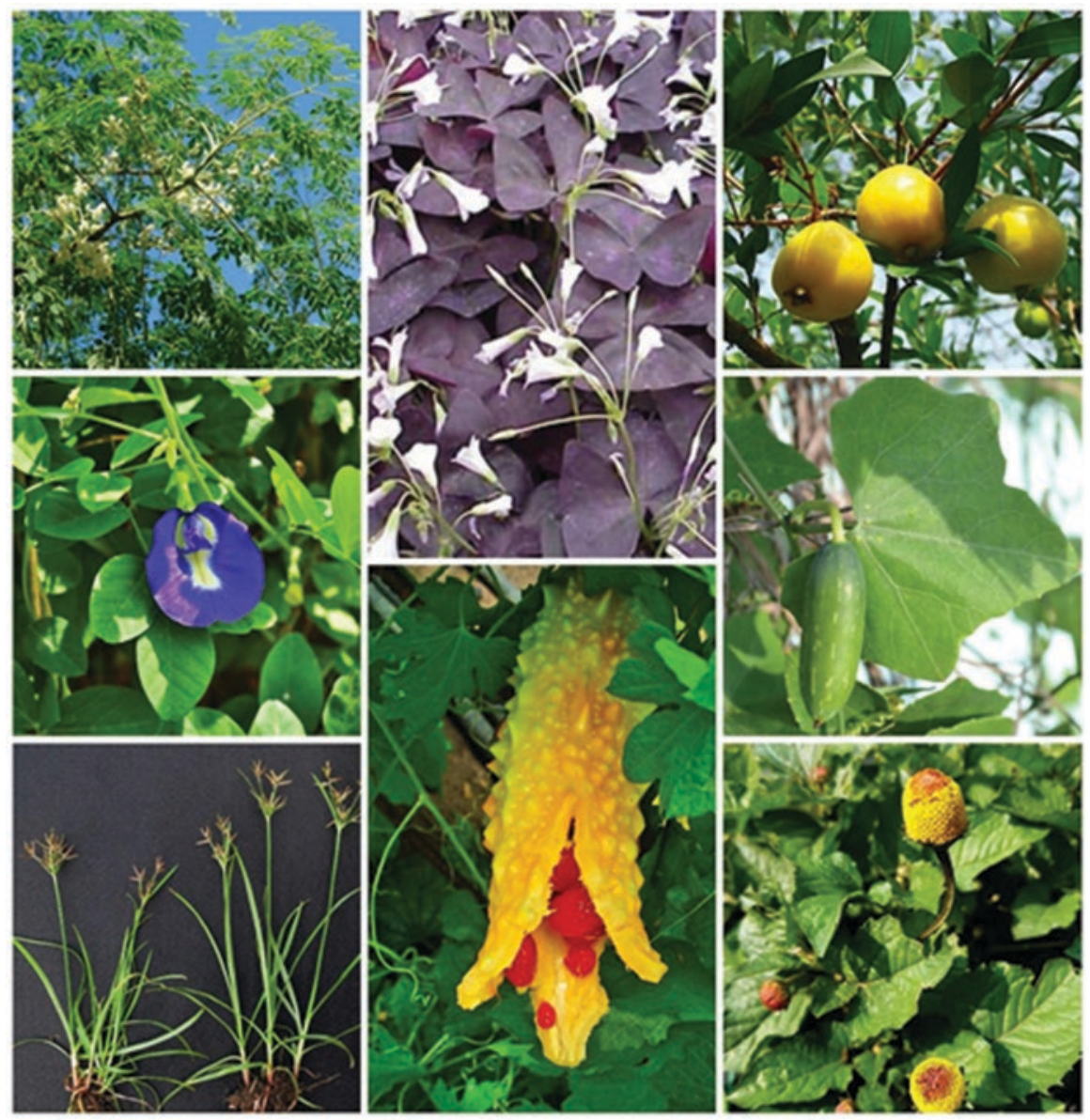

Fig. 3 UFP studied in 2019. (Source: LabNutrir collection)

That speech justifies that education with plants inside Nutrition Science widens up closed visions to sustainability, biodiversity, and soil care. In this manner, from the point of view of Nutrition formation, the data from Table 1 represents the culmination of an experiential learning process with studied plants and, to that point, points out proper attention by students to an integrated sight between food and ethnobotanical dimensions, which can be strategic to fight against nutritionism ideology.

Also, there is to say that LabNutrir is the first open sky laboratory in Brazil, and it enlightens a unique perspective for those who are involved with it. In this way, this aspect can be measured by Student 4's: "I believe that all of us from Nutrition had to pass by the Garden because it is an experience that they would not have in a conventional lab. There are primordial knowledge that can only me acquired with this method." 
Thereby, LabNutrir promotes necessary dialogue between Nutrition, Ethnobiology, and Anthropology with the elaboration of UFP data sheets. Besides that, it enables the improvement and reformulation of food assessment tools, complement studies in Ethnobiology and compiles data for inclusion of these plants in food and nutritional security within the local economy and biodiversity conservation (Reyes-García et al. 2019; Kasper-Pakosz et al. 2016; O’Neill et al. 2017). However, there are still limitations. Food composition data reveals significant differences related to agroecological zone, management techniques, soils, seasonality, and genetic diversity (Hunter et al. 2019).

On top of that, the data sheets encourage nutritional composition studies with these plants and combat harmful notions attributed to the condition of resistance and spontaneity of such plants, such as "scrubs", or weeds or even "famine foods." The data sheets also prioritize the spread of knowledge of the plant's nutritional character in a reliable manner (Jacob and Albuquerque 2020; do Nascimento et al. 2012).

The negative denotation "famine foods" refers to the memory of hunger and/or extreme poverty, in which ethnoculinary resources were essential to enable consumption of wild species during drought; this was revealed in research carried out on Pereskia aculeata, known as "the poor people's meat" in northeastern Brazil. ${ }^{6}$ Thus, culinary use is analyzed and compiled to enable an understanding of what are the difficulties and practical potentials of working with the species (do Nascimento et al. 2012). However, over time, the practices of collecting and preparing these foods have fallen into disuse, in a scenario of privilege given to the ultra-processed fruits of the industry lobby and UFP consumption associated only to the memory of hunger (Lang and Barling 2013).

To overcome the negative meaning of "famine foods" and to value plants from the local biome, LabNutrir's GBL method, by linking curricular components to the production and dissemination of UFP data sheets, brings these subjects closer to the student, in an effective theory-practice relationship based on the singular work involving each component and its problematization set.

In this scenario, the focus of working with plants develops contextualized learning, in which theoretical contents are experienced (agroecological management, botanical classification of plants, seasonality and plant development, methods of culinary elaboration of plant parts) and finally systematized (scientific name, origin, distribution and occurrence, nutritional information, and food uses).

In effect, the data sheets become instruments for scientific dissemination and support and development of educational activities in the community in free classes, cooking workshops and agricultural management (Jacob 2020).

We suggest that the active GBL methodology applied in LabNutrir is a positive strategy for incorporating knowledge of ethnobotany as a pillar of Nutrition, which, in addition to being biological, is socio-environmental. In turn, the GBL methodology mitigates botanical blindness (the inability to perceive plants in the environment)

\footnotetext{
${ }^{6}$ For the data P. aculeata, see in http://nutrir.com.vc/horta/Ficha_Pereskia.pdf
} 
(Salatino and Buckeridge 2016). Rediscovered and valued plants become new references for the promotion of biodiversity and sustainable diets, a reconciliation between nature and culture.

\section{An Answer for the Future: GBL for Professional Training of Nutritionists}

Reformulation of Nutrition curricular structures in Brazil, contemplating the complexities of knowledge and practices of SFS, is much needed. In view of the window found in interdisciplinary and interprofessional training of Nutrition professionals in knowledge, skills, and attitudes for the development of SFS, Jacob and Araújo (2019) proposed summarizing the conclusions of Brazilian experts concerning gaps in nutrition education and outlined aspects that limit the professional's performance, formalizing desires not yet addressed in the curricular structures of most courses. Among the recommendations for the proposed training paradigm, attention has been drawn to "pedagogical gardens structured as laboratories." It is in this sense that LabNutrir is placed. Recognizing the urgency of implementing a holistic approach to food, its practical scenario aims to strengthen the topic of biodiversity in Nutrition training (Jacob 2020).

Table 2 presents a systematization of the students' responses. We prioritized those promoting dialogue both for sustainable food systems and for food biodiversity.

These fragments from students' interviews are reflections and potential positive outcome indicators for the implementation of GBL method supporting capacity building toward sustainable food aystems.

Applying the lens of capacity building in education with respect to the demands of global agendas for achievement of Sustainable Development Goals, authors have been presenting capacity building as a critical point in training systematization. Capacity building refers to the process in which individuals strengthen and maintain the attitudes, skills, and knowledge needed to develop their goals over time (Baillie et al. 2009; Delisle et al. 2017).

The cognitive structure for knowing or for "learning to know" refers to the domain of knowledge acquisition instruments, whose foundation is the pleasure of understanding (Delors 2013).

As an example of that, Student 4 sayings allowed us to infer that "Composting" is a content of knowledge developed in our laboratory garden. In 2019, as part of the training activities, a course was being held in which one of the modules involved the proper environmental management of organic waste, with a focus on composting. The process was conducted by professors from UFRN, specialists in soil management and conservation, and included implementation of composting in our vegetable garden. In the words of our student, the "most sensational" experience refers to the "use of the composter." 
Table 2 Mastery of skills for the interviewed students

\begin{tabular}{l|l}
\hline Capacity building & Fragments of interest \\
\hline $\begin{array}{l}\text { Knowledge } \\
\text { Sustainable diets } \\
\text { and/or menus }\end{array}$ & $\begin{array}{l}\text { "I understand the impact in relation to waste that would be dumped in } \\
\text { nature and the importance of composting." (Student 4) } \\
\text { "I think that for me the [experience] that was most sensational, and I was } \\
\text { very interested in learning is the use of the composter. So much that we } \\
\text { had there in the garden, that we always did the 'turning' and using leftover } \\
\text { food from the laboratory and from home as well." (Student 4) } \\
\text { "I learned what UFP is. [...] benefits and methods of preparation. I would } \\
\text { never imagine that a certain plant, like purslane - [Portulaca oleracea], } \\
\text { could make a souffle" (Student 2) }\end{array}$ \\
\hline $\begin{array}{l}\text { Skills } \\
\text { Identify plants, } \\
\text { develop sustainable } \\
\text { diets and menus } \\
\text { with UFP }\end{array}$ & $\begin{array}{l}\text { "I discovered that there are specific ways to take pictures of plants"; "Now } \\
\text { I know how to pass on the street and identify" (Student 2) }\end{array}$ \\
\hline $\begin{array}{l}\text { Attitudes } \\
\text { Awareness of food } \\
\text { biodiversity }\end{array}$ & $\begin{array}{l}\text { "There are seedlings here at home that I brought from the garden, purslane } \\
\text { [P. oleracea] and ora-pro-nobis [Pereskia aculeata], I [...] have it here at } \\
\text { home and always use it in my food [...]" (Student 4) } \\
\text { "Now I see that places in disuse can become urban gardens.", (STUDENT } \\
\text { 1) } \\
\text { "Close to my house, I see that many people take out the chananas [Turnera } \\
\text { subulata], today I even asked them not to start. Whenever I can and I see } \\
\text { people destroying for lack of knowledge, I [...] try to talk and talk a little } \\
\text { more about them." (Student 2) } \\
\text { "[The vegetable garden] mainly changed the way I looked at the plants. } \\
\text { Before, I just looked at the color, [...] fruit. I see today with different eyes, } \\
\text { I observe more specific details. I have a new view on plants [...] now it is } \\
\text { mainly the role of the nutritionist to instruct on [UFP] [...]. It is a } \\
\text { differential for nutritionists who know and those who do not know the } \\
\text { project." (Student 2) }\end{array}$ \\
\hline
\end{tabular}

Source: Authors

These excerpts suggest the importance of the strategy, using gardens as a teaching method for acquisition of practical knowledge. Perhaps, the concrete experience mediated by the vegetable garden is the motivation necessary to learn a given subject, situation, or phenomenon with pleasure. A pleasurable form of learning, in addition to memorization, is situated as contextualized and meaningful learning, taken home from the institutional garden, as revealed by Student 4 above.

The construction of meaningful knowledge, through concrete experiences, echoes in the reports of students from another project, previous to ours, and very close to our ideals, the Garden/Horta of the Faculty of Public Health (FSP) of the University of São Paulo (USP):

After my participation in the project, I became even more concerned with the issue of the environment, with the reuse of organic waste, building a compost bin at home, and helping with the maintenance and care of plants

It was in the vegetable garden that I learned what a composter is, and an earthworm, and the importance of both in preserving the environment, mainly related to the issue of accumulating garbage (Higino et al. 2018, p. 27-9) 
The history of the FSP/USP Garden/Horta begins in 2014. As a teaching laboratory, it aims to be a space for observation, research, and teaching with the conviction that production and consumption of food from the garden contributes to healthy eating practices, promotes interaction with the environment, and encourages interdisciplinary studies (Higino et al. p.8).

The two Brazilian vegetable garden/laboratories present other similarities, such as acquisition of knowledge concerning UFP:

There was a UFP tasting, like Peixinho tea and mint leaves, it was very tasty. It was also really cool to be able to plant seedlings, have this contact with the land, and all of this is part of our involvement with food, isn't it? (Higino et al. 2018, p. 21)

In the previous section of this chapter, if our case study presented and discussed the relevance of lessons learned from data sheets, in which the UFP are studied in the biome in which they are located, for sustainable and socio-environmental nutrition, then the responses of project students provide evidence for the importance of rediscovering and valuing plants, making them new references for promotion of biodiversity and sustainable diets: "[...] I learned that [...] that we can insert UFP at times with more benefits than traditional [food]. Now I know that UFP open up a new range of options in the form of consumption" (Student 1, from LabNutrir).

In the wake of these experiences sharing an expanded proposal for a laboratory garden, a stage for contextualized learning, we are able to argue in favor of building skills and abilities for the nutritionist to act in the pursuit of sustainable food systems (SFS).

But, how does learning about composting relate to SFS? Our student replies: "Today, I understand how food can impact sustainable development, from when we produce, to when we will discard" (Student 1). Learning about composting makes it possible to concretize the notion of complexity in food systems, where care for each constituent element (environment, people, inputs, processes, infrastructure, institutions, markets, and commerce) is fundamental for the balance of the whole of its related activities (production, processing, distribution, and consumption of food) and the results of these activities (including social, economic, and environmental results).

Boff (2012, p.153) teaches us that one does not learn inside classrooms or closed into laboratory libraries, or even on Internet search sites. Students "must be led to experience nature, to discover biodiversity, to learn about the history of these landscapes [...] it is a plunge into the real world, to find Mother Earth."

The experience of learning mediated by mother nature "alive" in vegetable gardens reveals that in the immediate plain of "know-how," the acquisition and improvement of skills (identifying plants, preparing diets, and sustainable menus with UFP) are renewed in capacity building, necessary to become a professional capable of working in sustainable food systems.

Worldwide, other experiences have demonstrated the formative importance of this change toward sustainability of the food system.

At Appalachian State University, in the North Carolina, USA, university students from the Nutrition and Dietetics course $(n=12)$ participated in a program providing 
practical learning and service opportunities in vegetable gardens. The results relate, among the main benefits, greater vegetable intake, local food purchasing, and an increase in vegetable literacy (Gartman et al. 2016).

At the Sunshine Coast University, Queensland, Australia, a study with eight students from the Nutrition and Dietetics course in the universe surveyed $(n=14)$, revealed that, of the motivations of these university students to remain in volunteer work at the university community vegetable garden, the most common factor was the desire to learn and gain knowledge, particularly in themes related to vegetable gardens, sustainability, and healthy eating (Anderson et al. 2018).

Certainly the most powerful initiative is in Canada. The traditional University of British Columbia (UBC) has enjoyed the UBC Food System Project (UBCFSP) since 2001, with a series of courses at various levels of training, whose teachingapplied learning initiative aims to promote knowledge, skills, and experience in students so that they can serve as agents of change, as community leaders and as responsible global citizens. Despite its short time in existence, we can say that LabNutrir's experience also seeks to “offer students opportunities for applied learning, research, and professional development, to bring a positive impact to ecological and human health" (UBCFSP 2020).

The importance of the work articulated, between the dimensions of knowledge and doing, in capacity building for Sustainable and Socio-Environmental Nutrition, is realized. This is made possible by the fact that the GBL learning method transcends formal teaching and takes place through a unique experience in which the construction of knowledge and the development of skills are linked in a contextualized way, which is fundamental to the pursuit of Sustainable Development Goals/SDGs, leaving the rhetorical plane and facing in the garden, a starting point for problems of a transdisciplinary nature, and stimulating new learning paths.

As to development of attitudes and thoughts linked to ways of acting, feeling, and positioning oneself in relation to tasks in social life, the responses obtained suggest a certain degree of internalization of the concepts, behaviors, and facts, derived from the pedagogical experiences in the LabNutrir vegetable garden.

[The vegetable garden] mainly changed the way I look at plants. Before I just looked at the color, the fruit. I see today with different eyes, I observe more specific details. I have a new view on plants [...] now it is mainly the role of the nutritionist to teach on [UFP]. [...]. You can take your knowledge about UFP with you. It is a differential between nutritionists who know and those who do not know the project. (Student 2)

The professional training that acts for the transition of SFS necessarily passes through an awareness of food biodiversity (Table 2). As "learning to be," it becomes part of the person's total development - spirit and body, intelligence, sensitivity, aesthetic sense, personal responsibility, and spirituality (Delors 2013).

An inseparable development in the cognitive and "knowing how to do" dimensions, by changing "my worldview" (Student 1), can change the local context: "Now I see that places in disuse can become urban gardens." (Student 1); "Near my house, I see that many people remove the chananas [T. subulata], today I even 
asked them not to. Whenever I can and I see people destroying... for lack of knowledge, I [...] try to talk and say a little more about them." (Student 2).

Biodiversity becomes an incorporated attitude. Learning that promotes decongestion of botanical blindness. It is discovery that leads to attitudes supported by an awareness of food biodiversity: "There are seedlings here at home that I brought from the garden, purslane $[P$. oleracea $]$ and ora-pro-nobis $[P$. aculeata $]$, I [...] have it here at home and I always use it in my food [...]" (Student 4).

Although the number of students is not significant when considering the universe of Nutrition students at UFRN, it should be noted that all attended the project for 1 year. The results show that teaching and learning experiences focused on plants promote capacity building in food biodiversity. GBL is an answer that deals with the questions of the present and, in passing, strengthens bridges of the future for sustainable environments and food systems.

\section{Final Considerations}

The pedagogical method employed by LabNutrir, insofar as it establishes a contextualized teaching-practice-reflection relationship with food plants in the biome of their territory, advances the training of nutritionists able to promote sustainable diets. We understand that studying, disseminating, and enhancing UFP are an important strategy to expand and reframe food plants that are culturally acceptable and accessible, economically fair and accessible, and nutritionally adequate, safe, and healthy; and it is also fundamental to protecting and respecting biodiversity and ecosystems while optimizing natural resources. Basing capacity building in science that sees itself as sustainable and socio-environmental, and in which the teaching of food biodiversity can be performed from theory to practice in gardens, becomes an important pillar for the new professional profile, trained to work in sustainable food systems: a sensitive and proactive view from ethnobotanical and biocultural perspectives.

Although the universe of our case report is limited, we understand that our results and their implications contribute to the debate on training human resources in Nutrition toward having the competence to promote sustainable diets, in which biodiversity plays a central role.

Acknowledgments We would like to say thank you to the Pró-Reitoria de Extensão and to our Pró-Reitoria de Graduação, whose contribution of financial resources and quota of scholarships allow us to continue the actions of projects linked to LabNutrir with excellence. To the Pró-Reitoria de Administração (PROAD), who made it possible to translate this text. Also, we would express our gratitude to the members of our garden laboratory, whose dedication keeps LabNutrir's ideals enlightened. Finally, a special thank you to Michelle Cristine Medeiros Jacob, idealizer and creator of this open sky living lab, who has contributed to the first version of this manuscript with dedicated reading. 


\section{References}

Anderson C, Maher J, Wright H (2018) Building sustainable university-based community gardens: Volunteer perceptions of enablers and barriers to engagement and benefits received from volunteering in the Moving Feast. Cogent Soc Sci 4:1-19. https://doi.org/10.1080/23311886.20 18.1488211

Azevedo E, Rigon S (2016) Sistema Alimentar com base no conceito de sustentabilidade. In: Taddei J et al.(2nd ed) Nutrição em Saúde Pública. Rubio, São Paulo, p 467-478

Baillie E, Bjarnholt C, Gruber M, Hughes R (2009) A capacity-building conceptual framework for public health nutrition practice. Public Health Nutr 12:1031-1038. https://doi.org/10.1017/ S1368980008003078

Boff L (2012) Sustentabilidade: o que é o que não é, Petrópolis, RJ

Burlingame BA, Dernini S (2012) Sustainable diets and biodiversity. In: Food and Agriculture Organizations of the United Nations. International Scientific Symposium Biodiversity and Sustainable Diets United against Hunger (2010: Rome, Italy). Rome

BRASIL. INEP. Instituto Nacional de Estudos e Pesquisas Educacionais (2000) Exame Nacional do Ensino Médio: documento básico. Brasília

Brasil (2001) Institui diretrizes curriculares nacionais do curso de graduação em nutrição. Resolução CNE/CES 5, de 7 de novembro de 2001. Diário Oficial da União; Nov 9, Seção 1, p. 39. DCN/MEC/2001. Available at: http://portal.mec.gov.br/cne/arquivos/pdf/CES05.pdf. Accessed 29 Mar 2020

Creswell JW (2014) Investigação Qualitativa e projeto de pesquisa: escolhendo entre cinco abordagens. Edição em português: da Rosa SM. Porto Alegre

Delisle H, Shrimpton R, Blaney S et al (2017) Capacity-building for a strong public health nutrition workforce in lowresource countries. Bull World Health Organ 95:385-388. https://doi. org/10.2471/BLT.16.174912

Delors J (2013) The treasure within: Learning to know, learning to do, learning to live together and learning to be. What is the value of that treasure 15 years after its publication? Int Rev Educ 59:319-330. https://doi.org/10.1007/s11159-013-9350-8

Desmond D, Grieshop J, Subramaniam A (2004) Revisiting garden-based learning in basic education. FAO, Rome

do Nascimento VT, da Silva Vasconcelos MA, Maciel MIS, Albuquerque UP (2012) Famine Foods of Brazil's Seasonal Dry Forests: Ethnobotanical and Nutritional Aspects. Econ Bot 66:22-34. https://doi.org/10.1007/s12231-012-9187-2

Etkin N (2006) Edible medicines: an Ethnopharmacology of food. University of Arizona Press, Tucson

FAO (2010) The second report on the state of the world's plant genetic resources for food and agriculture. Journal of Medical Entomology, Rome

FAO (2013) Sustainable food systems concept and framework. Rome, Italy

FAO (2017) Guidelines on assessing biodiverse foods in dietary surveys. Rome, Italy

Forouhi NG, Unwin N (2019) Global diet and health: old questions, fresh evidence, and new horizons. Lancet 393:1916-1918. https://doi.org/10.1016/S0140-6736(19)30500-8

Gartman M, Ball L, Gutschall M et al (2016) Design and implementation of a garden-based service learning program for nutrition and dietetic students: a CBPR approach. J Nutr Educ Behav 48:S60. https://doi.org/10.1016/j.jneb.2016.04.160

Higino AF, Prager AC, Bertolini AM et al (2018) Histórias da horta da Faculdade de Saúde Pública. In: Faculdade Saúde Pública, USP. São Paulo

Hunter D, Borelli T, Beltrame DMO et al (2019) The potential of neglected and underutilized species for improving diets and nutrition. Planta 250:709-729. https://doi.org/10.1007/ s00425-019-03169-4

Jacob MCM (2020) Biodiversidade De Plantas Alimentícias Não Convencionais Em Uma Horta Comunitária Com Fins Educativos. DEMETRA Aliment Nutr Saúde 15:e44037. https://doi. org/10.12957/demetra.2020.44037 
Jacob MCM, Albuquerque UP (2020) Biodiverse food plants: Which gaps do we need to address to promote sustainable diets? Ethnobiol Conserv 9:1-6. https://doi.org/10.15451/ ec2020-04-9.09-1-6

Jacob MCM, Araújo FR (2019) Desenvolvimento de competências para Nutrição no contexto de Sistemas Alimentares Sustentáveis Capacity Building in Nutrition in the context of Sustainable Food Systems. a 1-18

Kasper-Pakosz R, Pietras M, Łuczaj Ł (2016) Wild and native plants and mushrooms sold in the open-air markets of south-eastern Poland. J Ethnobiol Ethnomed 12. https://doi.org/10.1186/ s13002-016-0117-8

Kinupp VF, De Barros IBI (2008) Protein and mineral contents of native species, potential vegetables, and fruits. Cienc e Tecnol Aliment 28:846-857. https://doi.org/10.1590/ s0101-20612008000400013

Kinupp VF, Lorenzi H (2014) Plantas alimentícias não convencionais (PANC) no Brasil: guia de identificação, aspectos nutricionais e receitas ilustradas. Instituto Plantarum de Estudos da Flora, São Paulo

Lang T, Barling D (2013) Nutrition and sustainability: An emerging food policy discourse. In: Proceedings of the Nutrition Society

Martinelli G, Moraes M (2013) Red book of flora of Brazil. Botanical Garden, Rio de Janeiro

O'Neill AR, Badola HK, Dhyani PP, Rana SK (2017) Integrating ethnobiological knowledge into biodiversity conservation in the Eastern Himalayas. J Ethnobiol Ethnomed 13:1-14. https:// doi.org/10.1186/s13002-017-0148-9

Perrenoud P (2008) Dez novas competências para ensinar. Porto Alegre

Recine E, Mortoza AS (2013) Consenso sobre habilidades e competências do nutricionista no âmbito da saúde coletiva. In: Observatório de Políticas de Segurança e Nutrição. Brasília

Reyes-García V, Powell B, Díaz-Reviriego I et al (2019) Dietary transitions among three contemporary hunter-gatherers across the tropics. Food Secur 11:109-122. https://doi.org/10.1007/ s12571-018-0882-4

Salatino A, Buckeridge M (2016) Mas de que te serve saber botânica? Estud Avancados 30:177_ 196. https://doi.org/10.1590/S0103-40142016.30870011

Scrinis G (2008) On the Ideology of Nutritionism. Gastronomica 8:39-48. https://doi.org/10.1525/ gfc.2008.8.1.39

Tumilowicz A, Neufeld LM, Pelto GH (2016) Using ethnography in implementation research to improve nutrition interventions in populations. Matern Child Nutr 11:55-72. https://doi. org/10.1111/mcn.12246

UBC Sustainability (2020) UBC Food System Project. https://sustain.ubc.ca/teaching-appliedlearning/seeds-sustainability-program/ubc-food-system-project. Accessed 29 Mai 2020

United Nations (2017) Transforming our world: the 2030 Agenda for Sustainable Development. New York

Willett W, Rockström J, Loken B et al (2019) Food in the Anthropocene: the EAT-Lancet Commission on healthy diets from sustainable food systems. Lancet 393:447-492. https://doi. org/10.1016/S0140-6736(18)31788-4 